\title{
Virucidal activity of Garcinia parvifolia leaf extracts in animal cell culture
}

\author{
Aziera Adnan ${ }^{1}$, Zeenathul Nazariah Allaudin ${ }^{1 *}$, Homayoun Hani ${ }^{2}$, Hwei-San Loh³ ${ }^{3}$ Teng-Jin Khoo ${ }^{4}$, \\ Kang Nee Ting ${ }^{4}$ and Rasedee Abdullah ${ }^{5}$
}

\begin{abstract}
Background: Garcinia species contain bioactive compounds such as flavonoids, xanthones, triterpernoids, and benzophenones with antibacterial, antifungal, anti-inflammatory, and antioxidant activities. In addition, many of these compounds show interesting biological properties such as anti-human immunodeficiency virus activity. Garcinia parvifolia is used in traditional medicine. Currently, the antiviral activity of G. parvifolia is not known.

Methods: This study was conducted to determine the effects of ethyl acetate $(45 \mathrm{~L} \mathrm{Ea)}$ ), ethanol $(45 \mathrm{~L} \mathrm{Et})$, and hexane ( $45 \mathrm{~L} \mathrm{H}$ ) leaf extracts of $\mathrm{G}$. parvifolia on the infectivity of pseudorabies virus (PrV) in Vero cells. The antiviral effects of the extracts were determined by cytopathic effect (CPE), inhibition, attachment, and virucidal assays.

Results: The $50 \%$ cytotoxicity concentration $\left(\mathrm{CC}_{50}\right)$ values obtained were $237.5,555.0$, and $<1.25 \mu \mathrm{g} / \mathrm{mL}$ for $45 \mathrm{~L}$ Ea, $45 \mathrm{LEt}$, and $45 \mathrm{~L} \mathrm{H}$, respectively. The $45 \mathrm{~L}$ Ea showed the greatest viral inhibition potency of $75 \%$ at $125 \mu \mathrm{g} / \mathrm{mL}$. Both $45 \mathrm{~L}$ Ea and $45 \mathrm{I}$ Et caused $100 \%$ residual viral inhibition at $250 \mu \mathrm{g} / \mathrm{mL}$. The selectivity index values for $45 \mathrm{~L} \mathrm{Ea}$, $45 \mathrm{~L}$ Et, and $45 \mathrm{~L} \mathrm{H}$ were $2.65,1.75$, and 0.10 showing that $45 \mathrm{~L}$ Ea had the greatest antiviral activity among the three extracts.
\end{abstract}

Conclusion: This study showed that ethyl acetate is the best solvent to be used to obtain extract from G. parvifolia leaves with potent antiviral activities.

Keywords: Pseudorabies virus, Ethyl acetate, Ethanol, Hexane, Plaque reduction assay, Cytopathic effect reduction assay, Inhibition assay, Virucidal assay, Selectivity index

\section{Background}

There are several ways by which therapeutic compounds interfere with viral replication. The antiviral effects can either be through prevention of viral attachment to host cell, binding to enzymes responsible for transcription, and prevention of cleavage of viral particles [1]. Viruses mutate over time and develop resistance to antiviral drugs and therapeutic compounds [2]. Thus, there is a need to discover and develop antiviral agents that do not become ineffective over time owing to development of resistance by the virus. But the pipeline of new drugs is drying up. There would be a tremendous benefit by integrating combinations of modern drugs with traditional medicinal plant extracts that have been used as folk

\footnotetext{
* Correspondence: zeenathulnazariah@gmail.com

${ }^{1}$ Department of Veterinary Pathology and Microbiology, Faculty of Veterinary Medicine, Universiti Putra Malaysia, 43400 Serdang, Selangor, Malaysia
} Full list of author information is available at the end of the article medicine to broaden the curing spectrum via generating synergistic effects.

Traditional medicinal trees are evergreen, abundant and available year round in tropical regions. Local communities used various parts of these trees in their traditional practice because of their high nutritive values but yet some of their detailed medicinal properties remain unknown. The plant studied, Garcinia parvifolia produces cherry-like fruit which is locally known as "asam kandis" or "asam kundong" [3], whilst the young leaves are sometimes eaten as a vegetable. The leaf extracts of this plant were screened against pseudorabies virus $(\operatorname{PrV})$. It is a broad host range herpesvirus, causes fatal encephalitis in a wide variety of animal species except its natural host, the adult pig [4-7]. Since PrV is not a human pathogen, it is safe to be used in a laboratory set-up. The virus can easily be grown in the laboratory thus it is practical and convenient to be used in the

(c) The Author(s). 2019 Open Access This article is distributed under the terms of the Creative Commons Attribution 4.0 International License (http://creativecommons.org/licenses/by/4.0/), which permits unrestricted use, distribution, and reproduction in any medium, provided you give appropriate credit to the original author(s) and the source, provide a link to the Creative Commons license, and indicate if changes were made. The Creative Commons Public Domain Dedication waiver (http://creativecommons.org/publicdomain/zero/1.0/) applies to the data made available in this article, unless otherwise stated. 
screening and development of antiviral drugs or compounds.

G. parvifolia which belongs to the family of Clusiaceae (Guttiferae), is native in tropical and subtropical countries of South East Asia such as here in Malaysia, Thailand, Brunei, and Indonesia [8, 9]. Garcinia is known to produce xanthones and benzophenones $[9,10]$ and many of these compounds show interesting biological activities including anti-human immunodeficiency virus activity $[9,10]$. There are at least 300 distinct Garcinia species and many contains bioactive compounds to include flavonoids, xanthones, triterpernoids, and benzophenones with beneficial biological activities [11-14]. The crude extracts of some parts of G. parvifolia have shown antiplasmodial, antioxidant, cytotoxic and antibacterial activities [15]. However, the antiviral properties of the G. parvifolia extract are not known. Since G. parvifolia has rather similar properties with other Garcinia sp, it potentially has antiviral activities and hence is of great interest to test in the current study. In this study, their leaf extracts were obtained by using either ethyl acetate, ethanol, or hexane and screened for the efficiency to inhibit PRV.

\section{Methods}

\section{Plant collection and crude plant extracts}

Approval for Garcinia parvifolia plant collection was obtained from Forestry Department Peninsular Malaysia. G. parvifolia leaf samples were obtained from the Sungai Congkak Recreational Forest Hulu Langat, Selangor, Malaysia $\left(3.209675^{\circ} \mathrm{N}, \quad 101.844327^{\circ} \mathrm{E}\right)$ and further authenticated by Forest Research Institute Malaysia (FRIM) botanist service of Richard Chung Cheng-Kong. The herbarium voucher specimens (herbarium code: UNMC45) were deposited at the Herbariums of the Faculty of Science, University of Nottingham Malaysia and FRIM. The ground plant leaves were subjected to sequential extraction procedures as described previously $[16,17]$. Briefly, crude plant extracts prepared from harvested leaves, using hexane and ethanol (RCI Labscan, Thailand) and ethyl acetate (R\&M Chemicals, Malaysia) solvents, that marked $45 \mathrm{~L} \mathrm{H}, 45 \mathrm{~L} \mathrm{Et}$, and 45 $\mathrm{L}$ Ea, respectively were provided by Dr. Teng Jin Khoo, the University of Nottingham, Malaysia following the extraction steps. Leaves of G. parvifolia were washed with sterile deionized water, shredded into small pieces, and let them dried in a closed room at $25-28^{\circ} \mathrm{C}$ for 2 weeks. The dried leaves were milled, weighed and soaked in 95\% ethanol at a fraction of 1:8 (fragment: ethanol) at room temperature for $24 \mathrm{~h}$. The leaf ingredients were then sequentially extracted according to solvent polarity of ethanol, followed by hexane and then ethyl acetate. Each plant extract was saturated three times before undergoing the reduced pressure rotary evaporation processing at $40^{\circ} \mathrm{C}$. The concentrated crude extracts were kept at $-20^{\circ} \mathrm{C}[17]$.

\section{Preliminary phytochemical analysis}

Several phytochemical tests were performed to confirm the presence of secondary metabolites: saponin, flavonoid, tannin, phenolic content, steroid and terpenoid. Approximately $12.5 \mathrm{mg}$ of each leaf extract from the $G$. parvifolia plant ( $45 \mathrm{~L} \mathrm{H}, 45 \mathrm{~L} \mathrm{Et}$, and $45 \mathrm{~L} \mathrm{Ea}$ ) was used.

\section{Test for saponin: frothing method}

Each extract was dissolved in $5 \mathrm{~mL}$ of purified water in the test tube covered with cork according to method established by Ibrahim and Ibrahim [18]. The samples were sonicated for $15 \mathrm{~min}$ at $40^{\circ} \mathrm{C}$. Samples that had particles were filtered before vigorously shaken for $30 \mathrm{~s}$ and left for another $45 \mathrm{~min}$. Persistence frothing formation showed the positive results for saponin [18].

\section{Test for flavonoid}

The flavonoid analysis was prepared following the Modified Shinoda Test [19]. Each extract was added with $5 \mathrm{~mL}$ of dimethyl sulfoxide (DMSO; Merck, Germany), next with 3-4 cm of magnesium turnings and 6 drops of $36 \%$ concentrated $\mathrm{HCl}$. Various colours like orange, pink, red to purple represent different flavonoids like flavones, flavonols, 2,3-dihydro derivates and xanthone, respectively.

\section{Test for tannin and phenolic content}

This test established by Mojab and colleagues [20] uses two reagents which are gelatin for protein precipitation and ferric chloride to confirm the presence of phenolic compound. Each extract was dissolved in $5 \mathrm{~mL}$ purified water and sonicated for $15 \mathrm{~min}$ at $40^{\circ} \mathrm{C}$. The volume was divided into three portions: one for control, the remaining for gelatin precipitation and phenolic content analysis. All portions were then added with 6 drops of $1 \%$ ferric chloride. White fog or precipitation with $5 \mathrm{~mL}$ of $1 \%$ gelatin, while brownish-green or blackish-blue colour shows the presence of phenolic compounds [20].

\section{Test for steroid and terpenoid}

Both steroid and terpenoid tests were accomplished using Salkowski Test [21, 22]. Every extract was dissolved in $5 \mathrm{~mL}$ of DMSO and sonicated for $15 \mathrm{~min}$ at $40^{\circ} \mathrm{C}$. One milliliter of solution was added with $1 \mathrm{~mL}$ chloroform and equal volume of concentrated sulphuric acid slowly at the side of the test tube. Upper layer exhibited red colour and sulphuric layer showed yellow colour with green fluorescence. These two layers observed and reddish-brown at the interface corresponds to the presence of terpenoid while the blue or green interface indicates steroid compound. 


\section{Pseudorabies virus (PrV)}

The stock PrV strain amorphous inclusion protein (AIP) used in this study was an established virus at the Virology Laboratory, Faculty of Veterinary Medicine, Universiti Putra Malaysia. Quantitation of stock virus was conducted on Vero cells (ATCC No. CCL-81) by using the plaqueforming assay. The virus was stored at $-80^{\circ} \mathrm{C}$.

\section{Vero cell culture}

Vero cells were grown and maintained in RPMI 1640 supplemented with $10 \%$ fetal bovine serum (FBS), $1 \%$ Penicillin $(100 \mathrm{U} / \mathrm{mL}), 1 \%$ Streptomycin $(100 \mathrm{mg} / \mathrm{mL})$, and $1 \%$ Fungizone $(2.5 \mathrm{mg} / \mathrm{mL})$. The cells were seeded into sterile 96-well and 24-well flat bottom plates. Vero cells were incubated under $5 \% \mathrm{CO}_{2}$ humidified atmosphere at $37^{\circ} \mathrm{C}$.

\section{Plant extract}

The plant extracts were dissolved in pure DMSO and diluted with sterile de-ionized water to a total volume of $1 \mathrm{~mL}$. The stock solution was dissolved for $48 \mathrm{~h}$ in either 10 or $50 \%$ DMSO to obtain 10 and $50 \mathrm{mg} / \mathrm{mL}$ extract concentrations, respectively and stored at $-20^{\circ} \mathrm{C}$.

\section{$50 \%$ tissue culture infectious dose $\left(\mathrm{TCID}_{50}\right)$}

Vero cells were seeded into flat-bottom 96-well microtiter plates at $2 \times 10^{4}$ cells/well and incubated for $24 \mathrm{~h}$ under $5 \% \mathrm{CO}_{2}$ humidified atmosphere at $37^{\circ} \mathrm{C}$. Serial dilution of virus stock $\left(10^{8} \mathrm{PFU} / \mathrm{ml}\right)$ was prepared in media with FBS. So the working stock was formed forth dilution that was $1 \times 10^{4} \mathrm{PFU} / \mathrm{ml}$, then incubated with the Vero cells for $72 \mathrm{~h}$. The cytopathic effect (CPE) and proportional distance (PD) were calculated using the following formula [23]; PD = (\% of wells infected at dilution $>50 \%)$ - (50\% infection) / (\% of wells infected at dilution $>50 \%)-(\%$ of wells infected at dilutions < 50\%). The tissue culture infectious dose $50 \%\left(\mathrm{TCID}_{50}\right)$ is calculated by using the following formula: $\mathrm{TCID}_{50}=10^{\log \text { total dilu- }}$ tion $>50 \%-(1 \times \log \mathrm{h})$.

\section{Pseudorabies virus quantification}

Vero cells $\left(1.6 \times 10^{5}\right.$ cells $)$ in RPMI 1640 containing $2 \%$ FBS were seeded in each well of a 24-well plate and incubated under $5 \% \mathrm{CO}_{2}$ humidified atmosphere at $37^{\circ} \mathrm{C}$ in for $24 \mathrm{~h}$. The medium was discarded, replaced with fresh medium and plates were again incubated under $5 \%$ $\mathrm{CO}_{2}$ humidified atmosphere at $37^{\circ} \mathrm{C}$ for $48 \mathrm{~h}$. The virus was diluted with fresh RPMI 1640 with 2\% FBS to obtain a working virus solution. One hundred microliters of virus suspension containing $1 \mathrm{X} 10^{7} \mathrm{PFU} \mathrm{PrV}$ was added to each containing Vero cells in $1 \mathrm{~mL}$ of $1 \%$ methylcellulose and 2\% FBS and the plate incubated rocking for $1 \mathrm{~h}$.
Infected cells were fixed with methanol and stained with $0.5 \%$ crystal violet solution for $30 \mathrm{~min}$. The number of plaques formed were counted and expressed as $\mathrm{PFU} / \mathrm{mL}$.

\section{Cytotoxicity assay}

The cytoxicity assay was conducted according to the method described by Serkedjieva and Ivancheva [24] and Malik et al. [17]. Confluent monolayer Vero cells in 96well flat-bottom plated were treated with G. parvifolia leaf extracts at $62.5,125,250,500$ and $1000 \mu \mathrm{g} / \mathrm{mL}$. Vero cells treated with various concentrations of DMSO $(100 \mu \mathrm{L}$ of either $0.078,0.157,0.3,0.625,1.25,2.5,5$ or $10 \%$ in PBS) served as positive controls. However, the final concentration of DMSO in the working concentration was less than $0.3 \%$. Nontreated Vero cells served as the negative control. Positive controls were treated with DMSO at the same concentrations as the plant extracts.

The plates were incubated under $5 \% \mathrm{CO}_{2}$ humidified atmosphere at $37^{\circ} \mathrm{C}$ for $48 \mathrm{~h}$. Twenty microliters of 0.5 $\mathrm{mg} / \mathrm{mL}$ MTT solution was added to each well and incubated under $5 \% \mathrm{CO}_{2}$ humidified atmosphere at $37^{\circ} \mathrm{C}$ in for $4 \mathrm{~h}$. The incubation solution was removed and replaced with $100 \mu \mathrm{L}$ of pure DMSO. The plates were shaken for $15 \mathrm{~min}$ before reading with a multiplate reader (Tecan Sunrise, Männedorf, Switzerland) at 570 $\mathrm{nm}$. The reference wavelength was set at $650 \mathrm{~nm}$. The $50 \%$ Cytotoxicity Concentration $\left(\mathrm{CC}_{50}\right)$ was determined using the following formula: $\mathrm{CC}_{50}$ determined by $(\Delta \mathrm{OD}=(\mathrm{OD}$ value of treated group $/(\mathrm{OD}$ value of medium control $) \times 100$ ) where $\mathrm{OD}_{\text {treatment }}$ is optical density for treatment group and $\mathrm{OD}_{\text {control }}$ for control. The assay was done in triplicates.

\section{Plaque reduction assay}

The experiment was performed according to the method described by Zhu et al. [25] with brief modifications. Confluent monolayer of Vero cells grown in 24-well culture plates were treated with $100 \mu \mathrm{l}$ of $37.5,75,150$, and $300 \mu \mathrm{g} / \mathrm{mL}$ for $45 \mathrm{~L}$ Ea; $25,50,100$, and $200 \mu \mathrm{g} / \mathrm{mL}$ for $45 \mathrm{~L} \mathrm{Et}$ and $2.5,5,10,20,40 \mu \mathrm{g} / \mathrm{mL}$ for $45 \mathrm{~L} \mathrm{H}$. Besides, 100 PFU per $100 \mu \mathrm{L}$ PrV was added and incubated at $37^{\circ} \mathrm{C}$ for $90 \mathrm{~min}$. The virus and extract mixture was discarded and $1 \mathrm{~mL}$ of $1 \%$ methylcellulose and $2 \%$ FBS mixture were added to the wells and the plate was incubated in $5 \% \mathrm{CO}_{2}$ humidified atmosphere at $37^{\circ} \mathrm{C}$ for $48 \mathrm{~h}$. Infected cells were fixed with methanol and stained with $0.5 \%$ crystal violet solution for $30 \mathrm{~min}$. The number of plaques was counted and 50\% inhibition concentration $\left(\mathrm{IC}_{50}\right)$ calculated by the following formula: $\mathrm{IC}_{50}=[1-$ $\left.\left(\mathrm{PFU}_{\text {Treatment }} / \mathrm{PFU}_{\text {Control }}\right)\right] \times 100$ where $\mathrm{PFU}_{\text {treatment }}=$ PFU of treatment and PFU $\mathrm{Pontrol}_{\mathrm{P}} \mathrm{PFU}$ all control cells. The assay was done in quadruplicates. 


\section{Inhibition assay}

The experiment was performed according to the method described by Zhu et, al. [25]. Confluent monolayers of Vero cells grown in 24-well culture plates were infected with $100 \mathrm{PFU}$ of $\mathrm{PrV}$ in $200 \mu \mathrm{L}$ reaction volume and incubated under $5 \% \mathrm{CO}_{2}$ humidified atmosphere at $37^{\circ} \mathrm{C}$ for $90 \mathrm{~min}$. The incubation solution was removed and $200 \mu \mathrm{L}$ of $62.5,125$, 250 , and $500 \mu \mathrm{g} / \mathrm{mL} 45 \mathrm{~L}$ Ea or $45 \mathrm{~L}$ Et; $1.25,2.5,5$, 10 , and $20 \mu \mathrm{g} / \mathrm{mL} 45 \mathrm{~L} \mathrm{H}$ was added as $1 \mathrm{~mL}$ in $1 \%$ methyl cellulose and 2\% FBS mixture. The plates were incubated at $37^{\circ} \mathrm{C}$ in $5 \% \mathrm{CO}_{2}$ humidified atmosphere for $48 \mathrm{~h}$. The cells were fixed and stained with $0.5 \%$ crystal violet and the $\mathrm{IC}_{50}$ was calculated as described for the plaque reduction assay.

\section{Attachment assay}

The assay was conducted according to the Logu et al., [26]. Confluent monolayer Vero cells were prechilled at $4{ }^{\circ} \mathrm{C}$ for $1 \mathrm{~h}$. Confluent monolayers of Vero cells were infected with $50 \mu \mathrm{L}$ of $1 \times 10^{2} \mathrm{PFU} / \mathrm{mL} \mathrm{PrV}$ in the presence of $100 \mu \mathrm{L}$ of $6.125,12.5,25,50$, or $100 \mu \mathrm{g} / \mathrm{mL} 45 \mathrm{~L} \mathrm{Ea}, 45 \mathrm{~L} \mathrm{Et}$, or $45 \mathrm{~L} \mathrm{H}$ extracts in $1 \%$ DMSO. Vero cells infected with PrV but not treated with extract served as positive control while those neither infected with $\operatorname{PrV}$ nor treated with extract served as the negative controls. The cells were chilled at $4{ }^{\circ} \mathrm{C}$ for $3 \mathrm{~h}$ and the incubating mixture removed. The cells were washed trice with PBS, supplemented with RPMI 1640 containing 10\% FBS, and incubated under $5 \% \mathrm{CO}_{2}$ humidified atmosphere at $37^{\circ} \mathrm{C}$ for 48 h. The cells were observed daily to determine the CPE. When 100\% CPE was observed, the cells were subjected to MTT assay as described in the cytotoxicity assay. The $\mathrm{IC}_{50}$ of the plant extract was determined as described earlier.

\section{Virucidal assay}

The experiment was performed according to the method described by Carlucci et. al. [27]. $1 \times 10^{6} \mathrm{PFU}$ $\operatorname{PrV}$ were mixed with 125,250 or $500 \mu \mathrm{g} / \mathrm{mL}$ of $45 \mathrm{~L}$ $\mathrm{Ea}, 62.5,125$ or $250 \mu \mathrm{g} / \mathrm{mL}$ of $45 \mathrm{~L} \mathrm{Et}$, and $1.25,2.5$, 5.0 or $10 \mu \mathrm{g} / \mathrm{mL}$ of $45 \mathrm{~L} \mathrm{H}$ and then incubated at $25^{\circ} \mathrm{C}$ for $6 \mathrm{~h}$. One hundred microliters of virus suspension or extract was mixed with $100 \mu \mathrm{L}$ RPMI media containing $2 \%$ FBS and added to confluent monolayer Vero cells in a 24-well plate and incubated at $37^{\circ} \mathrm{C}$ for $90 \mathrm{~min}$. The incubating mixture was removed and replaced with $1 \mathrm{~mL}$ of $1 \%$ methyl cellulose and 2\% FBS mixture and incubated under 5\% $\mathrm{CO}_{2}$ humidified atmosphere at $37{ }^{\circ} \mathrm{C}$ for $48 \mathrm{~h}$. Formed plaques were fixed with methanol and stained with $0.5 \%$ crystal violet solution for $30 \mathrm{~min}$. The number of plaques was counted and residual virus infectivity was determined by the following formula: Plaque formation $(\mathrm{PFU})=$ Number of plaques $\times(1 /$ viral inoculation $) \times(1 /$ diluted fold $)$. The $\mathrm{IC}_{50}$ was calculated using the formula described in the plaque reduction assay.

\section{MTT assay}

The 3-(4,5-dimethylthiazol-2-yl)-2,5-diphenyltetrazolium bromide (MTT) assay (Calbiochem ${ }^{\bullet}$, Germany) was conducted when the cytotoxicity and antiviral assays give $100 \%$ CPE results. The Vero cells were added to $20 \mu \mathrm{L}$ of MTT solution with a final concentration of $0.5 \mathrm{mg} / \mathrm{mL}$ in the 96-well plate and the plate wrapped in aluminium foil to protect from light. The Vero cells were reincubated under $5 \% \mathrm{CO}_{2}$ humidified atmosphere at $37^{\circ} \mathrm{C}$ for $4 \mathrm{~h}$. The incubating solution was removed and $100 \mu \mathrm{L}$ pure DMSO added to all wells to dissolve the formazan crystals. The plates were gently shaken for $15 \mathrm{~min}$ to dissolve formazan crystals. The absorbances were read with a multiplate reader [Sunrise, Tecan] at $570 \mathrm{~nm}$ with a reference wavelength of $650 \mathrm{~nm}$. The $\mathrm{CC}_{50}$ was determined as described in the cytotoxic assay.

\section{Data analysis}

Two-way ANOVA was used to determine the difference between means of experimental data followed by post/ hoc test using SPSS 19.0. Differences between means were considered significant at $P<0.05$.

\section{Results}

\section{Phytochemical constituents}

Six phytochemical constituents, namely saponin [18], flavonoid [19], tannin and phenolic [20] as well as terpenoid and steroid [21, 22] contents were successfully determined in $45 \mathrm{~L}$ extracts based on the established methods. Phytochemical analysis demonstrated that $45 \mathrm{~L}$ Et contained all the six constituents tested, namely the saponin, flavonoid, tannin, phenolic, terpenoid and steroid. $45 \mathrm{~L} \mathrm{Ea}$ and $45 \mathrm{~L}$ Et had rather similar phytochemical profiles except for $45 \mathrm{~L} \mathrm{Ea}$ lacked of saponin compound. $45 \mathrm{~L} \mathrm{H}$ contained terpenoid and steroid only. Saponin was only found in the $45 \mathrm{~L}$ Et. Terpenoid and steroid were found in the three extracts.

\section{Cytotoxicity}

The $45 \mathrm{~L} \mathrm{H} \mathrm{G}$. parvifolia leaf extract showed the highest cytotoxicity towards Vero cells with $\mathrm{CC}_{50}$ of $<1.25 \mu \mathrm{g} / \mathrm{mL}$ and with cytotoxicity score of 1 (Fig. 1) followed by $45 \mathrm{~L}$ Ea and $45 \mathrm{~L}$ Et with $\mathrm{CC}_{50}$ of 237 and $555.0 \mu \mathrm{g} / \mathrm{mL}$, respectively and both with cytotoxicity score of 3 . 

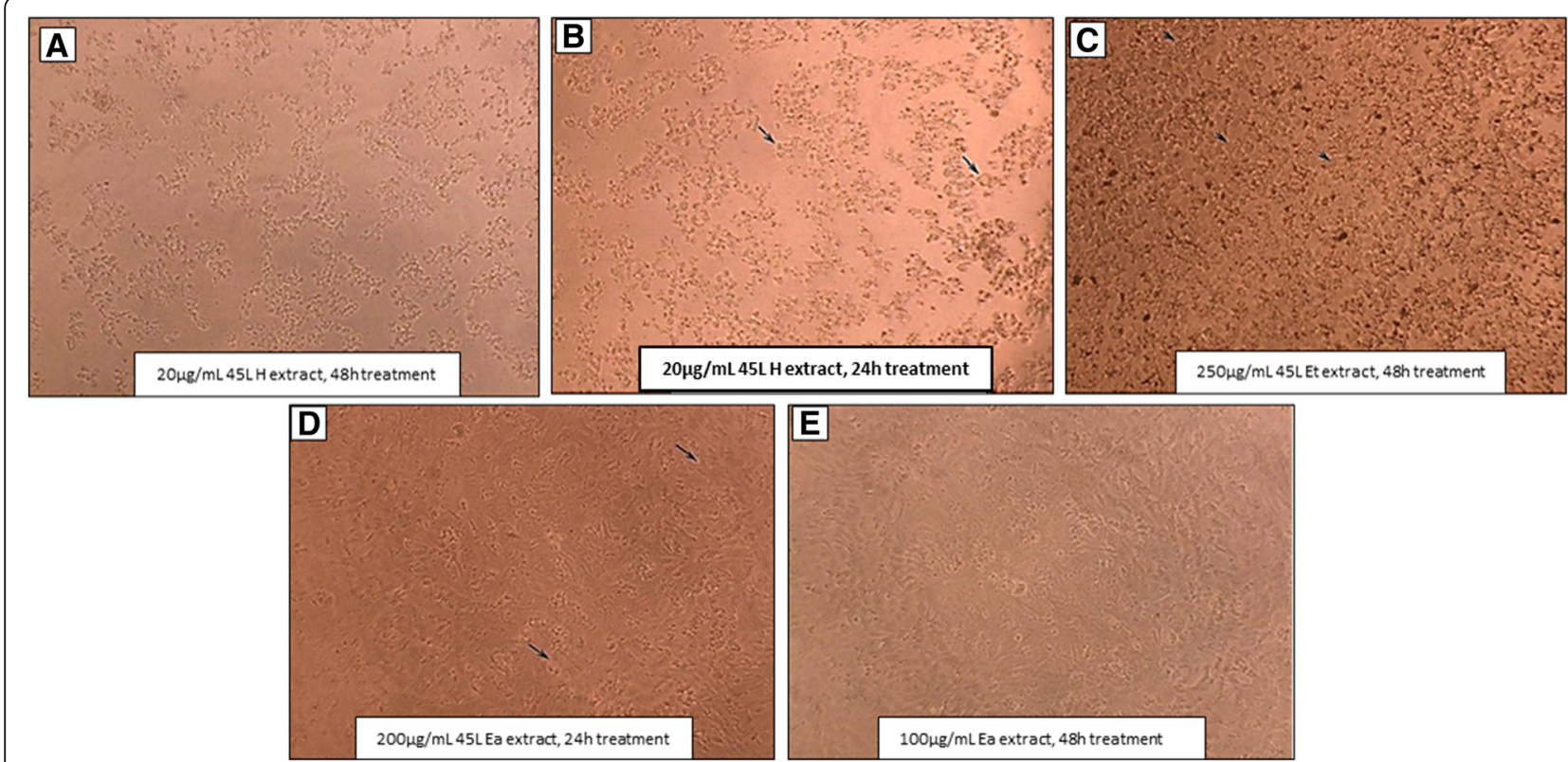

Fig. 1 Cytotoxicity scoring of Vero cells treated with G. parvifolia leaf extract. a Score 1 - severe cytotoxicity, no visible cells $(20 \mu \mathrm{g} / \mathrm{mL} 45 \mathrm{~L} \mathrm{H}$ extract at 48 h), b Score 2 - significant cytotoxicity, a few intact cells $(20 \mu \mathrm{g} / \mathrm{mL} 45 \mathrm{~L} \mathrm{H}$ extract at $24 \mathrm{~h})$, c Score 3 - Moderate cytotoxicity, altered cell morphology, cell well-spaced out $(250 \mu \mathrm{g} / \mathrm{mL} 45 \mathrm{~L}$ Et extract at $24 \mathrm{~h})$, d Score 4 - Mild cytotoxicity, altered cell morphology, cells closely spaced $(200 \mu \mathrm{g} / \mathrm{mL} 45 \mathrm{~L}$ Ea extract at $24 \mathrm{~h})$, e Score 5 - No cytotoxicity, normal cell morphology, dense cell distribution $(100 \mu \mathrm{g} / \mathrm{mL} 45 \mathrm{~L} \mathrm{Ea}$ extract at 48 h). (10x). $45 \mathrm{~L} \mathrm{H}, 45 \mathrm{~L}$, Et, and $45 \mathrm{~L}$ Ea is hexane, ethanol and ethyl acetate extracts, respectively from G. parvifolia leaves

\section{Plaque reduction assay}

There was significant $(p<0.05)$ dose-dependent Vero cell plaque reduction after treatment with $45 \mathrm{~L}$ Ea (Fig. 2).

\section{Viral inhibition}

All extracts irrespective of solvent used showed significant $(p<0.05)$ dose-dependent Vero cell plaque inhibition.
However the $\mathrm{CC}_{50}$ concentration for $45 \mathrm{~L} \mathrm{H}$ exceeded the safety level. Comparatively the $45 \mathrm{~L}$ Ea showed better inhibition $(75 \%)$ of plaque formation than $45 \mathrm{~L} \mathrm{Et} \mathrm{(26 \% )} \mathrm{(Fig.} \mathrm{3).}$

\section{Viral attachment}

Extracts, $45 \mathrm{~L} \mathrm{Ea}$ and $451 \mathrm{Et}$ showed the greatest dosedependent inhibition of viral attachment to Vero cells

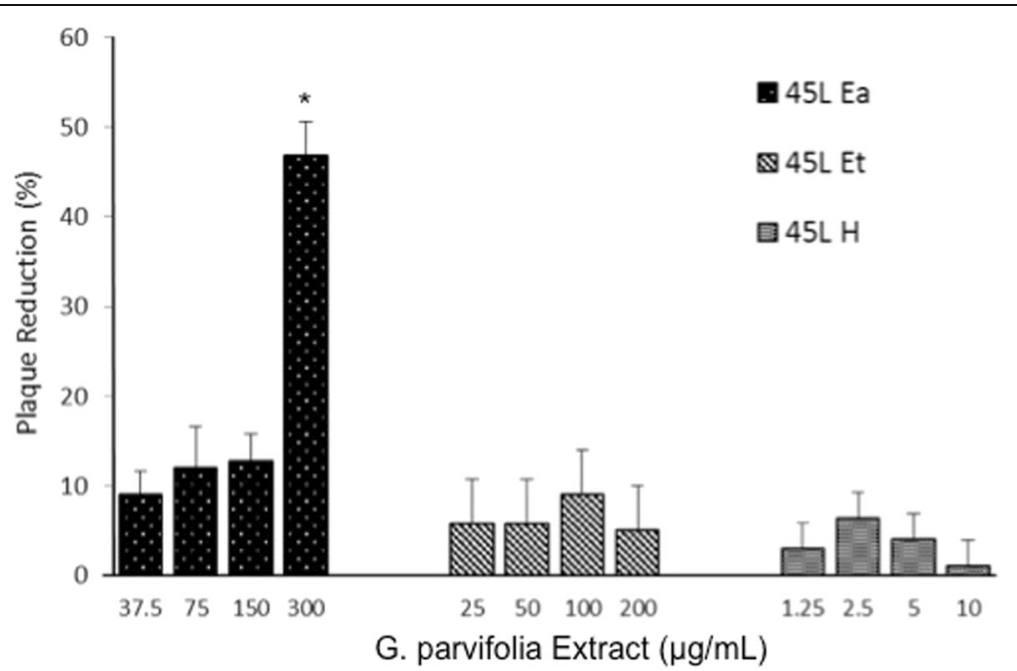

Fig. 2 Effect of G. parvifolia extracts on Vero cell plaque reduction. Plaque inhibition is observed in cells treated with $45 \mathrm{~L}$ Ea only at a concentration-dependent manner. $45 \mathrm{~L} \mathrm{H}, 45 \mathrm{~L}$ Et, and $45 \mathrm{~L}$ Ea are G. parvifolia hexane, ethanol, ethyl acetate leaf extracts, respectively. (*) indicates significant difference between individual extracts in each concentration at $p<0.05$ 


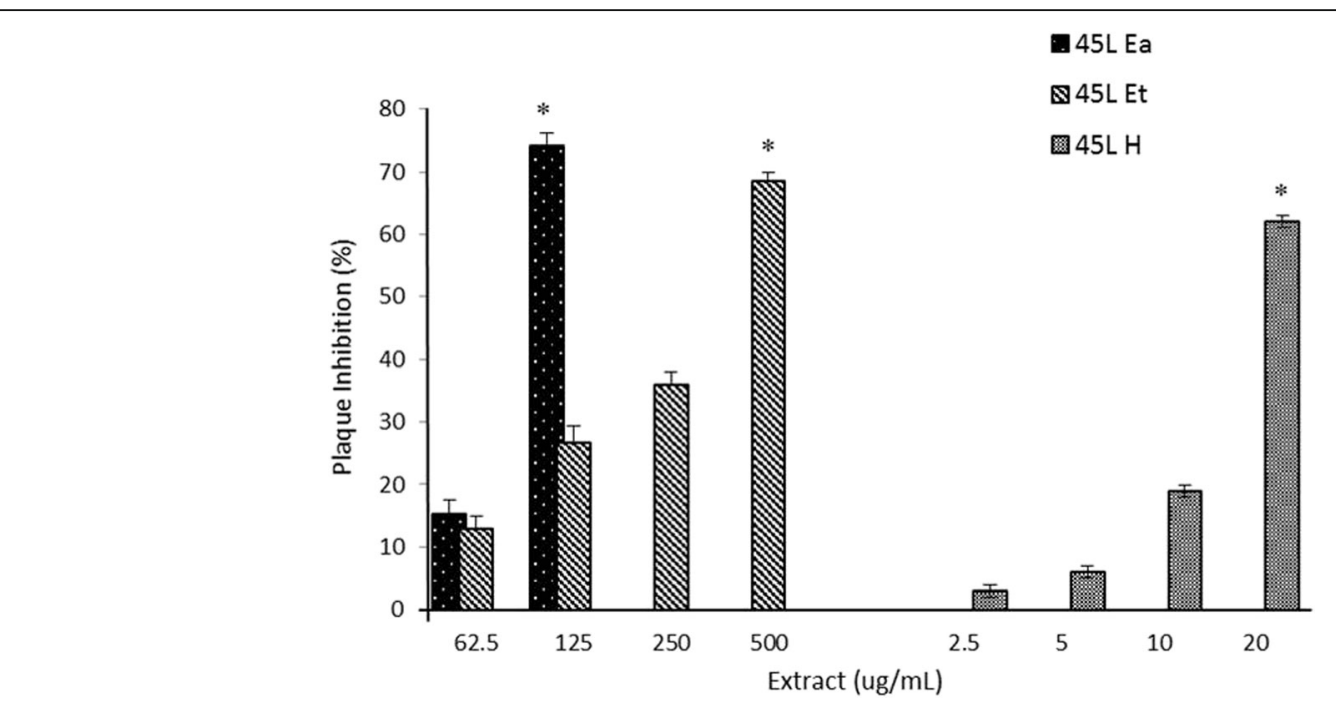

Fig. 3 Effect of G. parvifolia extracts on Vero cell plaque inhibition. The greatest inhibitory effect was observed in the cell treated with $45 \mathrm{~L}$ Ea followed by $45 \mathrm{~L}$ Et. $45 \mathrm{~L} \mathrm{H}, 45 \mathrm{~L} \mathrm{Et}$, and $45 \mathrm{~L}$ Ea are G. parvifolia hexane, ethanol and ethyl acetate leaf extracts, respectively. $\left.{ }^{*}\right)$ indicates significant difference between individual extracts in each concentration at $p<0.05$

(Fig. 4). The $45 \mathrm{~L} \mathrm{H}$ extract was not effective at inhibiting viral attachment to cells.

\section{Virucidal effect}

The $45 \mathrm{~L}$ Ea and $45 \mathrm{~L}$ Et showed almost complete virucidal activity at all concentrations used in the study. The $45 \mathrm{~L}$ Ea had better antiviral effect than $45 \mathrm{~L}$ Et with residual infectivity of 1 and $4 \%$, respectively (Fig. 5).

\section{Antiviral activity}

The selectivity index $(\mathrm{SI})\left[\mathrm{CC}_{50} / \mathrm{IC}_{50}\right]$ values for $45 \mathrm{~L} \mathrm{Ea}$, $45 \mathrm{~L} \mathrm{Et}$, and $45 \mathrm{~L} \mathrm{H}$ were $2.65,1.75$, and 0.10 , respectively. The SI showed that the $45 \mathrm{~L}$ Ea had the greatest antiviral activity followed y $45 \mathrm{~L}$ Et. The $45 \mathrm{~L} \mathrm{H}$ had minimal antiviral activity.

\section{Discussion}

This study focused on the three crude leaf extracts of $G$. parvifolia, namely $45 \mathrm{~L} \mathrm{H}, 45 \mathrm{~L} \mathrm{Et}$, and $45 \mathrm{~L} \mathrm{Ea}$, which

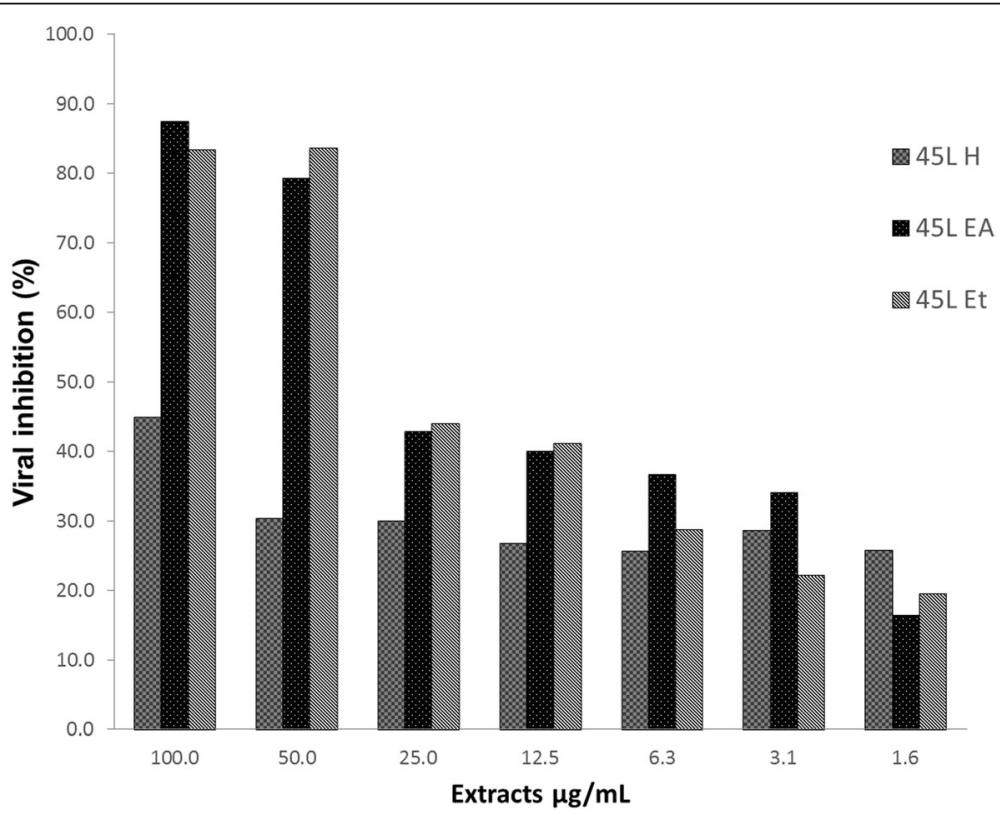

Fig. 4 Effect of G. parvifolia extract on inhibition of viral attachment to Vero cells. $45 \mathrm{~L} \mathrm{H}, 45 \mathrm{~L}$ Et, and $45 \mathrm{~L}$ Ea are G. parvifolia hexane, ethanol and ethyl acetate leaf extracts, respectively 


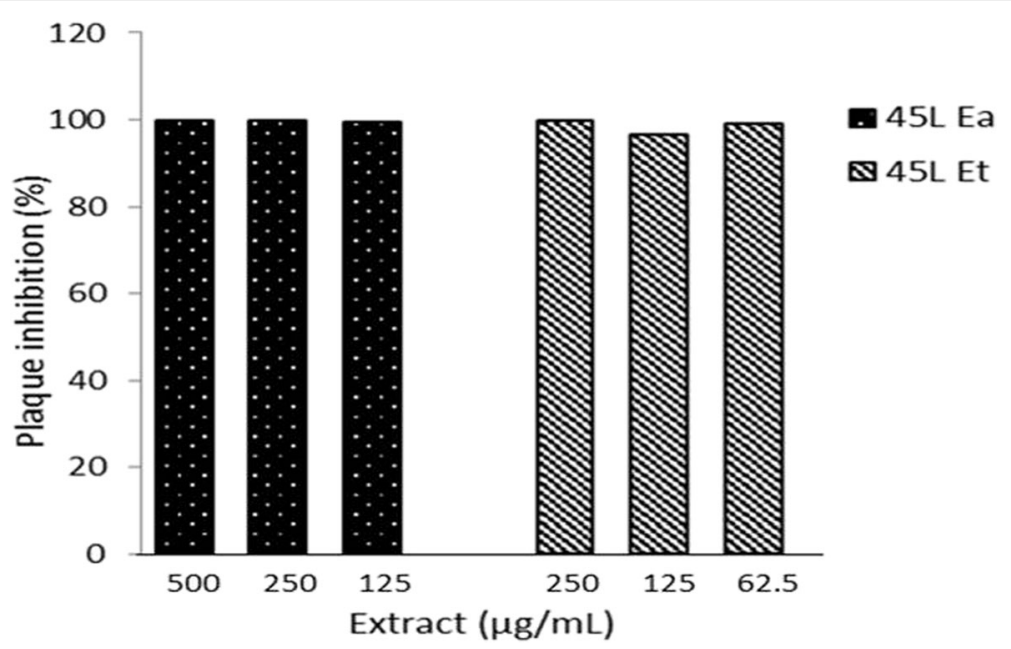

Fig. 5 Virucidal activity of $G$. parvifolia extracts. The $45 \mathrm{~L}$ Ea and $45 \mathrm{~L}$ Et showed almost complete virucidal activity. $45 \mathrm{~L} H$ did not have any virucidal activity. $45 \mathrm{~L} \mathrm{H}, 45 \mathrm{~L}$ Et, and $45 \mathrm{~L}$ Ea are G. parvifolia hexane, ethanol and ethyl acetate leaf extracts, respectively

were extracted via ethyl acetate, ethanol and hexane solvents, respectively. The phytochemical constituents of these crude extracts were elucidated (Table 1). Based on the findings, $45 \mathrm{~L}$ Et contained all six phytochemical constituents tested and $45 \mathrm{~L}$ Ea contained five of them except saponin and the non-polar $45 \mathrm{~L} \mathrm{H}$ did not contain saponin, tannin and phenolic contents. Among these, saponin and tannin are indeed very common secondary metabolites for plant kingdom, which possess good antioxidant activities. The presences of different classes of chemical constituents such as flavonoids, phenolics, terpenoids and steroids in $45 \mathrm{~L}$ are rather conformed to those isolated from different parts of $G$. parvifolia including leaves, twigs, latex, fruits and barks $[8,11]$. In fact, flavonoids and terpenoids isolated from plants had been reported to contain antiviral properties, particularly against Chikungunya virus [28] and severe acute respiratory syndrome coronavirus [29].

Besides, further extraction and separation processes have yielded purer compounds from G. parvifolia as reported in previous studies. For instance, four novel prenylated depsidones had been isolated from the chloroform soluble fraction of the leaves of G. parvifolia. [30]. The leaf extracts also displayed the presence of a new benzoquinone derivative, namely parvifoliquinone and six other known compounds namely parvifoliol B, C (phloroglucinols), parvifoliol E (benzopyran derivatives), garcidepsidone B (depsidone), nigrolineaisoflavone A (isoflavone-like compound) and mangostinone (xanthone) [31].

Some depsidones have shown to be active against HIV by inhibiting the viral integrase [32]. Using molecular screening and docking investigations, certain Garcinia phytochemicals, including garcidepsidone had been reported to be potential inhibitors to inhibit the dengue viral replication inside the host cell with the help. Further in-vitro investigations require confirming their efficacy [33].

Clusianone had been isolated in abundance from the leaves of G. parvifolia through hexane extraction [34]. Recently, the anti-proliferative potential of structurally modified clusianone and its derivatives has been shown $[35,36]$. A significant correlation was reported on the structure activity relationship of clusianone against Respiratory Carcinoma Cells via cytotoxicity assay [36].

Table 1 Phytochemical analysis on Garcinia parvifolia $45 \mathrm{~L}$ extracts

\begin{tabular}{|c|c|c|c|c|c|c|}
\hline \multirow[t]{2}{*}{ Sample } & \multicolumn{6}{|c|}{ Type of Analysis } \\
\hline & Saponin & Flavonoid & Tannin & Phenolic & Terpenoid & Steroid \\
\hline $45 \mathrm{~L} \mathrm{H}$ & $-(W)$ & $\begin{array}{l}-(D) \\
\text { yellow }\end{array}$ & $-(W)$ & $-(W)$ & $\begin{array}{l}+(\mathrm{D}) \\
\text { reddish brown }\end{array}$ & $\begin{array}{l}+(D) \\
\text { yellow with green fluorescence }\end{array}$ \\
\hline $45 \mathrm{~L} \mathrm{Ea}$ & $-(W)$ & $\begin{array}{l}+(\mathrm{D}) \\
\text { pink }\end{array}$ & $\begin{array}{l}+(W) \\
\text { white fog }\end{array}$ & $\begin{array}{l}+(\mathrm{W}) \\
\text { dark blue }\end{array}$ & $\begin{array}{l}+(\mathrm{D}) \\
\text { reddish brown }\end{array}$ & $\begin{array}{l}+(D) \\
\text { yellow with green fluorescence }\end{array}$ \\
\hline $45 \mathrm{~L} \mathrm{Et}$ & $\begin{array}{l}+(W) \\
\text { frothing }\end{array}$ & $\begin{array}{l}+(D) \\
\text { pink }\end{array}$ & $\begin{array}{l}+(W) \\
\text { white fog }\end{array}$ & $\begin{array}{l}+(\mathrm{W}) \\
\text { dark blue }\end{array}$ & $\begin{array}{l}+(\mathrm{D}) \\
\text { reddish brown }\end{array}$ & $\begin{array}{l}+(D) \\
\text { yellow with green fluorescence }\end{array}$ \\
\hline
\end{tabular}

- = constituent was not present in extract

$+=$ constituent was present in extract

(D) = extract was dissolved in DMSO solvent

(W) = extract was dissolved in purified water 
The strong toxic effect of $45 \mathrm{~L} \mathrm{H}$ extract towards Vero cells at minimal dose concentration, with CC50 of $<1.25 \mu \mathrm{g} / \mathrm{mL}$, in comparison to $45 \mathrm{~L} \mathrm{Ea} \mathrm{(CC50} \mathrm{of}$ $237)$ and $45 \mathrm{~L}$ Et $(555.0 \mu \mathrm{g} / \mathrm{mL})$, could predict either a prominent cytotoxicity or the anti-proliferative effect of clusianone,

Previously, primary screening isolated 20 xanthones from plants of the Guttiferae family that have inhibitory effects on human herpesvirus 4 (HHV-4) also known as the Epstein-Barr virus (EBV). Xanthones, particularly 1,3,7-trihydroxy-2-(3-methyl-2-butenyl) xanthone, dulxanthone-B and latisxanthone-C, seemed to significantly inhibit EBA early antigen (EBV-EA), one of the viral genes required for the initiation complex at the lytic origin of viral replication in Raji cells [37]. Mangiferin with a broad spectrum beneficial biological activities, was the first xanthone shown to be pharmacologically effective for the treatment of diseases caused by herpesvirus, [38]. One of the effects of the xanthones is the inhibition of HIV-1 reverse transcriptase. Among xanthones, prenylated xanthones is restricted to the plant species of the family Guttiferae [38]. Prenylated xanthones namely mangostin and $y$-mangostin, isolated from G. mangostana are active against HIV-1 protease, preventing proteolytic cleavage during retroviral replication [38]. A recent investigation submitted a set of 272 xanthones to molecular docking examination and the results suggested that the xanthones could be suitable key components of agents to possess antiviral properties [39]. In fact, prenyl groups have been predicted to be important in protein-protein binding because of their specialized prenyl-binding domains that facilitate attachment to cell membranes. Therefore, a few lead compounds and their derivatizations could be screened using a structural-based docking method, or high-throughput screening methods for serving as a proof of concept for feasible viral target.

Although, there are a few studies that determined the antiviral effect of several Garcinia species [10, 40-42], reports were almost null on G. parvifolia. Owing to the limited antiviral research that has been done on this species, this study aims to enlighten researchers on the effect of G. parvifolia on PrV-infected Vero cells. It was shown that G. parvifolia ethyl acetate $(45 \mathrm{~L} \mathrm{Ea})$ and ethanol $(45 \mathrm{~L} \mathrm{Et})$ extracts particularly, did not only reduce but in fact almost completely inhibited Vero cell plaque formation. The antiviral effects of the extracts are proposed to occur through several mechanisms. The extracts inhibited viral infection of Vero cells as shown by reduction in plaque formation when $\operatorname{PrV}$ was firstly incubated with the extracts before exposure to Vero cells. The extracts also inhibited attachment of the virus to the cells. When the virus was allowed to infect Vero cells, the infected cells treated with G. parvifolia extract, plaque formation was inhibited. Similarly, when Vero cells were treated with extract-virus mixture, plaque formation was reduced. These effects were most prominent with $45 \mathrm{~L} \mathrm{Ea}$ treatment. This finding suggests that the extract did not only inhibit cell infection by herpesviruses but also prevents viral replication of infected cells. The antiviral effect of G. parvifolia extracts are deemed to be virucidal. The virucidal property is only true for the ethyl acetate $(45 \mathrm{~L} \mathrm{Ea})$ and ethanol $(45 \mathrm{~L} \mathrm{Et})$ extracts, and not for the non-polar hexane $(45 \mathrm{~L} \mathrm{H})$ extract. These more polar extracts caused almost total inhibition of plaque formation by the PrV-infected cells.

To realize the potential of a plant product as an antiviral compound, its mechanism of activity must be ascertained. It is important to differentiate between viral particle inactivation or virucidal activity from antiviral activity. Direct viral particle inactivation is an early effect where the virus is inactivated before it infects the cells while antiviral activity is the killing or suppression of replication ability of the virus. It would be ideal in virus infections for the treatment drug to possess both virucidal and antiviral activities. In our study, both the G. parvifolia ethyl acetate $(45 \mathrm{~L} \mathrm{Ea})$ and ethanol $(45 \mathrm{~L} \mathrm{Et})$ extracts presented with good virucidal activities of $>90 \%$, and the effects of the extracts are partially on the inhibition of viral attachment and adsorption into target cells. The G. parvifolia hexane $(45 \mathrm{~L} \mathrm{H})$ extract did not show similar activity on Vero cells.

Among approaches used in the determination of antiviral activity of natural compounds is the inhibition of viral DNA replication and reverse transcriptase. Most natural antiviral agents may act only on a limited number of viruses, because the viruses are prone to mutations that render the compounds eventually becoming ineffective $[43,44]$. Antiviral compound should be highly effective while showing minimal toxicity to normal cells and tissues. One way determining potential of antiviral compound is by calculating the SI. In this study, the SI value of ethyl acetate ( $45 \mathrm{~L} \mathrm{Ea}$ ) extract was higher than either the ethanol $(45 \mathrm{~L} \mathrm{Et})$ or hexane $(45 \mathrm{~L} \mathrm{H})$ extract, indicating it has more potent antiviral activity. The results also suggest that the non-polar hexane $(45 \mathrm{~L} \mathrm{H})$ extract was most toxic to Vero cells among the three extracts, thus may not be a suitable candidate as antiviral agent. The difference of phytochemical constituents between $45 \mathrm{~L}$ Ea (showing the highest antiviral potency) and $45 \mathrm{~L} \mathrm{H}$ was the additional flavonoids, tannins and phenolics, which were extracted by ethyl acetate solvent. It might be possible that these constituents are responsible for the potent antiviral activities. It is worthy to mention that flavonoids, tannins, and phenolics had been found very important to inhibit different stages in the HIV replication cycle, where three of them act at the virus adsorption stage; flavonoids and tannins disable the reverse transcription and phenolics stop the viral integration in the human genome [32]. Besides, more 
recently, flavonoids of plant origin were found effective to combat against Chikungunya virus [28].

Based from a previous report on anti-bacterial screening, the hexane extract of the leaves of G. parvifolia did not show any antibacterial activity, while both hexane and ethyl acetate extracts of stem bark, root and fruit show strong antibacterial activity, especially against Staphyloccocus aureus [15]. Therefore, different parts of the plants possess diverse compounds and the extraction of compounds is influenced by the solvent used [45]. In this study, ethyl acetate was the best solvent for the bioactive extraction of G. parvifolia leaves, followed by ethanol; meanwhile, hexane did not seem to produce extracts with biological activity against PrV.

\section{Conclusion}

The antiviral activity of the G. parvifolia extracts seemed to occur at several stages of the replication cycle. The multiple antiviral effects of the extracts are suggested to occur through the interference of viral attachment and traverse across cell membrane, cytoplasmic transport, and viral genome replication. Therefore, the antiviral effect of the G. parvifolia ethyl acetate $(45 \mathrm{~L} \mathrm{Ea})$ and ethanol $(45 \mathrm{~L} \mathrm{Et})$ extracts is suggested to occur through several mechanisms and not solely virucidal. This study suggests that the G. parvifolia extracts prevent viral replication in infected cells, particularly the $45 \mathrm{~L}$ Ea containing the flavonoids, tannins and phenolics which could be the constituents that are responsible for the potent antiviral activities. Therefore, future works will be emphasized on the pure compounds isolation from these $45 \mathrm{~L} \mathrm{Ea}$ extract and to study the mechanisms of antiviral action triggered by these pure bioactives.

\section{Abbreviations}

ATCC: American Type Culture Collection; $\mathrm{CC}_{50}$ : The cytotoxic concentrations; CPE: Cytopathic effect; DMEM: Dulbecco modified Eagle medium; DMSO: Dimethyl sulfoxide; EA: Ethyl acetate; $E_{50}$ : 50\% effect concentration; ET: Ethanol; FBS: Fetal bovine serum; $\mathrm{H}$ : Hexane; $\mathrm{I}_{50}$ : 50\% inhibitory concentration; MRSA: Methicillin-resistant Staphylococcus aureus; MTT: 3-(4,5-Diamethylthiazol-2yl)-2,5-diphenyltetrazolium bromide; PBP2a: Penicillin-binding protein; PFU: Plaque forming unit; PrV: Pseudorabies virus; RPMI: Roswell Park Memorial Institute; SI: Selective index; $\mathrm{TCID}_{50}$ : 50\% tissue culture infective dose

\section{Acknowledgements}

The authors would like to thank and acknowledge the Ministry of Science and Technology of Malaysia (MOSTI) for providing financial support. In addition, we thank Universiti Putra Malaysia for providing the research environment and necessary facilities.

\section{Authors' contributions}

AA: Carried out data collection, analysis and preparation of manuscript draft. ZNA: Supervised the study, was project leader and helped to draft the manuscript. $\mathrm{HH}$ : Has been involved in drafting the manuscript and revising it critically for important intellectual content. HSL: Has made substantial contributions to conception, design and virological experimentation; wrote part of the manuscript and critical reviewed the manuscript. TJK: Conducted the phytochemical analysis on the plant extracts and wrote part of the manuscript. KNT: Has made substantial contributions to conception and design. RA: Has been involved revising the manuscript critically for important intellectual content. All authors have given final approval of the version to be published.

\section{Funding}

This work was partially supported by the Ministry of Science and Technology of Malaysia (MOSTI) under the research project number; 03-02-04-0563SR0008/05-06. This funding helped researchers to design the study, purchase all those needed chemicals and materials, collect data, interpretation them and manuscript preparation.

\section{Availability of data and materials}

The datasets used and/or analysed during the current study available from the corresponding author on reasonable request.

\section{Ethics approval and consent to participate}

Ethics approval in this study was not required. We have obtained the approval from Forestry Department Peninsular Malaysia for plant sample (Garcinia parvifolia) collection.

This statement has been added in the METHODS: Plant Collection and Crude Extracts section.

\section{Consent for publication \\ Not applicable.}

\section{Competing interests}

The authors declare that they have no competing interests.

\section{Author details}

${ }^{1}$ Department of Veterinary Pathology and Microbiology, Faculty of Veterinary Medicine, Universiti Putra Malaysia, 43400 Serdang, Selangor, Malaysia.

${ }^{2}$ Department of Cell Biology and Physiology, School of Medicine, University North Carolina, Chapel Hill, NC 27599, USA. 3School of Biosciences, University of Nottingham Malaysia, Jalan Broga, 43500 Semenyih, Selangor, Malaysia.

${ }^{4}$ School of Pharmacy, University of Nottingham Malaysia, Jalan Broga, 43500 Semenyih, Selangor, Malaysia. ${ }^{5}$ Department of Veterinary Laboratory Diagnostics, Faculty of Veterinary Medicine, Universiti Putra Malaysia, 43400 Serdang, Selangor, Malaysia.

Received: 4 December 2017 Accepted: 30 June 2019

Published online: 10 July 2019

\section{References}

1. MacLachlan NJ, Dubovi EJ. Fenner's veterinary virology. 4th ed. San Diego: Academic; 2011. p. 197-8.

2. Hsuan SL, Chang SC, Wang SY, Liao TL, Jong TT, Chien MS, Lee WC, Chen SS, Liao JW. The cytotoxcity to leukemia cells and antiviral effects of Isatis indigotica extracts on pseudorabies virus. J Ethnopharmacol. 2009;123(1): $61-7$.

3. Siti Hawa AH, Jeffrey RF, Mohd Fadzelly AB. Phytochemicals content, antioxidant activity and acetylcholinesterase inhibition properties of indigenous Garcinia parvifolia fruit. Biomed Res Int. 2013;1:1-7.

4. Enquist LW, Husak PJ, Banfield BW, Smith GA. Infection and spread of alphaherpesviruses in the nervous system. Adv Virus Res. 1998;51:237.

5. Field HJ, Hill TJ. The pathogenesis of pseudorabies in mice following peripheral inoculation. J Gen Virol. 1974;23(2):145-57.

6. McCracken JA, Barcikowski B, Carlson JC, Green K, Samuelsson B. The physiological role of prostaglandin F2alpha in corpus luteum regression. Adv Biosci. 1973:9:599.

7. Pensaert MB, Kluge JP. Pseudorabies virus (Aujeszky's disease). In: Pensaert MB, editor. Virus infections of porcines. Amsterdam: Elsevier; 1989. p. 39-65.

8. Rukachaisirikul V, Naklue W, Phongpaichit S, Hutadilok Towatana N, Maneenoon K. Phloroglucinols, depsidones and xanthones from the twigs of Garcinia parvifolia. Tetrahedron. 2006:62:8578-85.

9. Ittipon S, Wisanu M, Tawanun S, Thunwadee R, Sarot C, Surat L. Biphenyl and xanthone derivatives from the twigs of a Garcinia sp. (Clusiaceae). Phytochem Lett. 2014;8:77-80.

10. Gustafson KR, Blunt JW, Munro MHG, Fuller RW, McKee TC, Cardellinall JH, McMahon JB, Cragg GM, Boyd MR. The Guttiferones, HIV-inhibitory benzophenones FromcSymphonia globulifera, Garcinia Livingstonei, Garcinia ovalifolia and Clusia rosea. Tetrahedron. 1992;48(46):10093-102. 
11. Waterman PG, Hussain RA. Systematic significance of xanthones, benzophenones and biflavonoids in Garcinia. Biochem Syst Ecol. 1983;11(1):21-8.

12. Jabit ML, Wahyuni FS, Khalid R, Israf DA, Shaari K, Lajis NH, Stanslas J. Cytotoxic and nitric oxide inhibitory activities of methanol extracts of Garcinia species. Pharm Biol. 2009;47(11):1019-26.

13. Chin YW, Kinghorn AD. Structural characterization, biological effects, and synthetic studies on xanthones for mangosteen (Garcinia mangostana), a popular botanical dietary supplement. Mini Rev Org Chem. 2008;5:355-64.

14. Padhye S, Ahmad AO, Dandawate PN, Deshpande J, Swamy KV, Sarkar FH. Fluorinated 2'-hydroxychalcones as garcinol analogs with enhanced antioxidant and anticancer activities. Bioorg Med Chem Lett. 2010;20(19): 5818-21.

15. Syamsudin S, Kumala BS. Screening of some extracts from Garcinia parvifolia Miq. (Guttiferae) for antiplasmodial, antioxidant, cytotoxic and antibacterial activities. Asian J Plant Sci. 2007:6:972-6.

16. Othman M, Loh HS, Wiart C, Khoo TJ, Lim KH, Ting KN. Optimal methods for evaluating antimicrobial activities from plant extracts. J Microbiol Methods. 2011;84:161-6

17. Malik FZ, Allaudin ZN, Loh HS, Nee TK, Hani H, Abdullah R. Antiviral and virucidal activities of Duabanga grandiflora leaf extract against Pseudorabies virus in vitro. BMC Complement Altern Med. 2016;23(16):139.

18. Ibrahim $\mathrm{H}$, Ibrahim $\mathrm{H}$. Phytochemical screening and toxicity evaluation on the leaves of Argemone mexicanna Linn (Papaveraceae). Int J Pure Appl Sci. 2009:3:39-43.

19. Jones W, Kinghorn A. Extraction of plant secondary metabolite. In: Sarker S, Latif Z, Gray A, editors. Natural product isolation. 2nd ed. Totowa: Humana Press Inc.; 2006.

20. Mojab F, Kamalinejad M, Ghaderi N, Vahidipour H. Phytochemical screening of some species of Iranian plants. Iran J Pharm Res. 2003;2(2):77-82.

21. Edeoga $\mathrm{H}$, Okwu D, Mbaebie B. Phytochemical constituents of somme Nigerian medicinal plants. Afr J Biotechnol. 2005;4:685-8.

22. Kumar A, llavarasan $R$, Jayachandran $T$, Decaracam M, Aravindhan P. Phytochemical investigation on tropical plant Syzgium cumini from Kattuppalayam Erode District Tamil Nadu South India. Pak J Nutr. 2009;8:83-5.

23. Reed $L$, Muench $H$. A simple method of estimating fifty percent endpoints. Am J Hyg. 1938;27:493-7.

24. Serkedjieva J, Ivancheva S. Antiherpes virus activity of extracts from the medicinal plant Geranium sanguineum L. J Ethnopharmacol. 1998;64(1):59-68.

25. Zhu L, Li Y, Li S, Li H, Qiu Z, Lee C, Lu H, Lin X, Zhao R, Chen L, Wu JZ, Tang $\mathrm{G}$, Yang W. Inhibition of influenza A virus (H1N1) fusion by benzenesulfonamide derivatives targeting viral hemagglutinin. PLoS One. 2011;6(12):e29120.

26. Logu AD, Loy G, Pellerano ML, Bonsignore L, Schivo ML. Inactivation of HSV1 and HSV-2 and prevention of cell-to-cell virus spread by Santolina insularis essential oil. Antivir Res. 2000;48:177-85.

27. Carlucci MJ, Ciancia M, Matulewicz MC, Cerezo AS, Damonte EB, Antiherpetic activity and mode of action of natural carrageenans of diverse structural types. Antivir Res. 1999;43(2):93-102.

28. Lani R, Hassandarvish P, Shu MH, Phoon WH, Chu JJ, Higgs S, Vanlandingham D, Abu Bakar S, Zandi K. Antiviral activity of selected flavonoids against Chikungunya virus. Antivir Res. 2016;133:50-61.

29. Wen CC, Kuo YH, Jan JT, Liang PH, Wang SY, Liu HG, Lee CK, Chang ST, Kuo CJ, Lee SS, Hou CC, Hsiao PW, Chien SC, Shyur LF, Yang NS. Specific plant terpenoids and lignoids possess potent antiviral activities against severe acute respiratory syndrome coronavirus. J Med Chem. 2007:50(17):4087-95.

30. Xu JY, Chiang YP, Lai HY, Vittal JJ, Wu HX, Tan HKB, Imiyabir Z, Goh HS. Cytotoxic Prenylated depsidones from Garcinia parvifolia. J Nat Prod. 2000; 63:1361-3.

31. Rukachaisirikul V, Trisuwan K, Sukpondma Y, Phongpaichit S. A new benzoquinone derivative from the leaves of Garcinia parvifolia. Arch Pharm Res. 2008;31:17-20.

32. Vlietinck AJ, de Bruyne T, Apers S, Pieters LA. Plant-derived leading compounds for chemotherapy of human immunideficiency virus (HIV) infection. Planta Med. 1998;64:97-109.

33. ul Qamar T, Mumtaz A, Ashfaz UA, Azhar S, Fatima T, Hassan M, Hussain SS, Akram W, Idrees $\mathrm{S}$. Computer aided screening of phytochemicals from Garcinia against the dengue NS2B/NS3 protease. Bioinformation. 2014;10: $115-8$.

34. Sree Vaneesa N, Janet WPC, Mohammed KB, Ibrahim MT, Teng-Jin K. A P212121 polymorph of (+)-clusianone. Acta Cryst. 2013;69:1799-800.
35. Garnsey MR, Matous JA, Kwiek JJ, Coltart DM. Asymmetric total synthesis of $(+)$ - and (-)-Clusianone and (+)- and (-)Clusianone methyl enol ether via ACC alkylation and evaluation of their anti-HIV activity. Bioorg Med Chem Lett. 2011;21:2406-9.

36. Sree VN, Wai-Ling K, Teng-Jin K. Structural derivatization of Clusianone and in vitro cytotoxicity evaluation targeting respiratory carcinoma cells. Planta Med Lett. 2016;3(01):10-3.

37. Ito C, Itoigawa M, Furukawa H, Rao KS, Enjo E, Bu P, Takayasu J, Tokuda H, Nishino $\mathrm{H}$. Xanthones as inhibitors of Epstein-Barr virus activation. Cancer Lett. 1998;132:113-7.

38. Negi JS, Bisht VK, Singh P, Rawat MSM, Joshi GP. Naturally occurring xanthones: chemistry and biology. J Appl Chem. 2013. https://doi.org/1 $0.1155 / 2013 / 621459$

39. Freddy $A B$, Ericsson C-B. Molecular docking and multivariate analysis of xanthones as antimicrobial and antiviral agents. Molecules. 2015;20(7): 13165-204.

40. Reutrakul V, Anantachoke N, Pohmakotr M, Jaipetch T, Sophasan S, Yoosok C, Kasisit J, Napaswat C, Santisuk T, Tuchinda P. Cytotoxic and anti-HIV-1 caged xanthones from and fruits of Garcinia hanburyi. Planta Med. 2007;73: $33-40$.

41. Reutrakul V, Anantachoke N, Pohmatkotr M, Jaipetch T, Yoosok C, Kasisit J, Napaswa C, Panthong A, Santisuk T, Prabai S, Kongsaeree P. Tuchinda. AntiHIV-1 and anti-inflammatory Lupanes from the leaves, twigs and resin of Garcinia hanburyi. Planta Med. 2010;76(4):368-71.

42. Lin Y-M, Anderson H, Flavin MT, Pai Y-HS. In vitro anti-HIV activity of biflavonoids isolated from Rhus seccedanea and Garcinia multiflora. J Nat Prod. 1997;60:884-8

43. Ferraris $\mathrm{O}$, Lina $\mathrm{B}$. Mutations of neuraminidase implicated in neuraminidase inhibitors resistance. J Clin Virol. 2008;41:13-9.

44. Morfin F, Thouvenot D. Herpes simplex virus resistance to antiviral drugs. J Clin Virol. 2003:26(1):29-37.

45. Sultana B, Anwar F, Ashraf M. Effect of extraction solvent/technique on the antioxidant activity of selected medicinal plant extracts. Molecules. 2009;14: 2167-80.

\section{Publisher's Note}

Springer Nature remains neutral with regard to jurisdictional claims in published maps and institutional affiliations.
Ready to submit your research? Choose BMC and benefit from:

- fast, convenient online submission

- thorough peer review by experienced researchers in your field

- rapid publication on acceptance

- support for research data, including large and complex data types

- gold Open Access which fosters wider collaboration and increased citations

- maximum visibility for your research: over $100 \mathrm{M}$ website views per year

At $\mathrm{BMC}$, research is always in progress.

Learn more biomedcentral.com/submissions 